\title{
Design, baseline characteristics, and retention of African American light smokers into a randomized trial involving biological data
}

Lisa Sanderson Cox ${ }^{1 *}$, Babalola Faseru ${ }^{1}$, Matthew S Mayo ${ }^{2}$, Ron Krebill ${ }^{2}$, Tricia S Snow ${ }^{1}$, Carrie A Bronars ${ }^{1}$, Nicole L Nollen ${ }^{1}$, Won S Choi ${ }^{1}$, Kolawole S Okuyemi ${ }^{3,4,9}$, Gary A Salzman ${ }^{5}$, Neal L Benowitz ${ }^{6}$, Rachel F Tyndale ${ }^{7}$, Jasjit S Ahluwalia ${ }^{4,8,9}$

\begin{abstract}
Background: African Americans experience significant tobacco-related health disparities despite the fact that over half of African American smokers are light smokers (use $\leq 10$ cigarettes per day). African Americans have been under-represented in smoking cessation research, and few studies have evaluated treatment for light smokers. This paper describes the study design, measures, and baseline characteristics from Kick It at Swope III (KIS-III), the first treatment study of bupropion for African American light smokers.

Methods: Five hundred forty African American light smokers were randomly assigned to receive bupropion (150mg bid) $(n=270)$ or placebo $(n=270)$ for 7 weeks. All participants received written materials and health education counseling. Participants responded to survey items and provided blood samples for evaluation of phenotype and genotype of CYP2A6 and CYP2B6 enzymes involved in nicotine and bupropion metabolism. Primary outcome was cotinine-verified 7-day point prevalence smoking abstinence at Week 26 follow-up.

Results: Of 2,628 individuals screened, 540 were eligible, consented, and randomized to treatment. Participants had a mean age of 46.5 years and $66.1 \%$ were women. Participants smoked an average of 8.0 cigarettes per day, had a mean exhaled carbon monoxide of $16.4 \mathrm{ppm}$ (range 1-55) and a mean serum cotinine of $275.8 \mathrm{ng} / \mathrm{ml}$. The mean Fagerström Test for Nicotine Dependence was 3.2, and $72.2 \%$ of participants smoked within 30 minutes of waking. The average number of quit attempts in the past year was 3.7 and 24.2\% reported using pharmacotherapy in their most recent quit attempt. Motivation and confidence to quit were high.

Conclusion: KIS-III is the first study designed to examine both nicotine and bupropion metabolism, evaluating CYP2A6 and CYP2B6 phenotype and genotype in conjunction with psychosocial factors, in the context of treatment of African American light smokers. Of 1629 smokers screened for study participation, only 18 (1.1\%) were ineligible to participate in the study because they refused blood draws, demonstrating the feasibility of recruiting and enrolling African American light smokers into a clinical treatment trial involving biological data collection and genetic analyses. Future evaluation of individual factors associated with treatment outcome will contribute to advancing tailored tobacco use treatment with the goal of enhancing treatment and reducing health disparities for African American light smokers.

Trial Registration: ClinicalTrials.gov: NCT00666978
\end{abstract}

\footnotetext{
* Correspondence: Icox@kumc.edu

'Department of Preventive Medicine and Public Health, University of Kansas

Medical Center, Kansas City, KS, USA

Full list of author information is available at the end of the article
} 


\section{Background}

Tobacco use remains the leading preventable cause of disease and death in the United States [1]. Differences in patterns of tobacco use, access to treatment, and treatment outcomes between African American and white smokers have been well documented [2-7]. Compared to white smokers, African American smokers consume fewer cigarettes per day and are more likely to be classified as "light" smokers, smoking 10 or fewer cigarettes per day [8-11]. However, African American smokers are more likely to smoke high-tar and mentholated cigarettes $[12,13]$, to inhale more deeply [14], and to have a slower rate of nicotine metabolism [15] and show higher levels of cotinine per cigarette smoked [4,16,17]. Unfortunately, African American smokers are less likely to receive treatment, have poorer treatment outcomes, and suffer a disproportionately greater share of tobacco-related morbidity and mortality [1], making treatment of these smokers a continued public health priority. African American smokers historically have been under-represented in smoking cessation research and few studies have focused on treating light smokers $[18,19]$.

The current paper describes the study design and baseline characteristics from Kick It at Swope III (KISIII), a clinical trial of bupropion and health education counseling for African American light smokers. KIS-III is the third in a series of studies aimed at enhancing tobacco use treatment for African American smokers. The first KIS-I trial [20] was a double-blind, placebocontrolled trial that demonstrated the efficacy of sustained release bupropion in African American moderate to heavy smokers, those who smoked 10 or more cigarettes per day (cpd). Because over $50 \%$ of African American smokers are light smokers, the second KIS trial (KIS-II) focused on treating light smokers (1-10 cpd) and evaluated nicotine gum compared to placebo in combination with either motivational interviewing (MI) or health education (HE) counseling using a $2 \times 2$ factorial design $[21,22]$. Findings from KIS-II showed no benefit of nicotine gum, but demonstrated a doubling in rates of abstinence for smokers who received HE compared to MI counseling [22]. The lack of response to nicotine replacement therapy may have been due to under-dosing related to low dose of drug used ( $2 \mathrm{mg}$ rather than $4 \mathrm{mg}$ ), insufficient frequency of dosing, or poor adherence. For these reasons, a nonnicotine medication was considered for the present trial of African American light smokers. Of note, we explored more completely the issues of biomarkers and found neither carbon monoxide nor cotinine were strongly associated with self-reported smoking level in this light smoking population [4]. We also found that abstinence was influenced by genetically variable rates of nicotine metabolism [15].
The present KIS-III study was designed to build upon KIS-I and KIS-II findings. Because bupropion was found to be effective in African American moderate to heavy smokers, KIS-III was designed to extend this evaluation within African American light smokers, in combination with effective HE counseling. Based on prior research, bupropion treatment is expected to reduce the rewarding effects of smoking and aid withdrawal reduction for smokers independent of smoking level. In addition, we continued investigation of genetic and pharmacokinetic influences on cessation in KIS-III.

Because genetic, sociocultural, and pharmacological determinants of smoking vary across racial and ethnic groups and may impact tobacco use treatment, empirical evaluation of these factors in the context of smoking cessation intervention has been recommended $[15,16,23]$. The consistent disparity of finding higher cotinine levels per cigarette in African American smokers is likely due to greater intake of nicotine per cigarette smoked combined with slower nicotine metabolism $[4,17]$. The enzyme CYP2A6 $[24,25]$ and genetic variation in CYP2A6 is associated with multiple smoking behaviors including cessation, as well as tobacco-related disease risk [25-28]. Genetic variation in the CYP2B6 gene, coding the enzyme responsible for bupropion metabolism, is also associated with smoking cessation in the context of both bupropion and placebo treatment [29-31]. KIS-III was designed to extend previous studies of African American smokers by incorporating biological evaluation of both nicotine and bupropion metabolism, and the genetic variation in the main metabolic enzymes CYP2A6 and CYP2B6, in addition to other smoking and psychosocial factors, within this clinical trial of light smokers. This paper describes the study design, baseline characteristics and retention of African-American light smokers into a smoking cessation treatment trial that involves biological data collection.

\section{Methods \\ Study Design}

This is a randomized, placebo-controlled study with the primary aim of evaluating the efficacy of sustained release bupropion in combination with health education (HE) counseling for smoking cessation among urban African-American light smokers. Five hundred and forty African-American light smokers recruited from the Kansas City metropolitan area were randomly assigned to an active bupropion and health education (HE) counseling $(T x)$ condition $(n=270)$ or to a placebo and HE comparison $(C)$ condition $(n=270)$. The primary outcome was 7-day point prevalence smoking abstinence at 6 months confirmed with salivary cotinine. The study was conducted at an urban community-based clinic that serves predominantly low-income African-American 
patients. A Community Advisory Board (CAB) composed of African-American community members assisted in the implementation of the study. The study procedures were approved and monitored by the University of Kansas Medical Center Human Subjects Committee.

\section{Study Sample \\ Participant Recruitment}

Recruitment started in December 2007 and ended in October 2009. The final 6-month follow-up was completed in May 2010. Participants were recruited through clinic- and community-based efforts. Clinic-based efforts included use of fliers, posters, physician letters, pharmacy inserts and lobby recruitment at the primary study site, Swope Health Services in Kansas City, two Swope affiliate clinics, and two regional hospitals (the University of Kansas Medical Center and Truman Medical Center). Community-based efforts included advertisement through radio, television, and newspapers, informative presentations at health fairs and libraries, local businesses and religious organizations, and website communication. Participants received referral cards to distribute to friends who smoked. Newsletters providing current project information, recruitment and success stories, and tips for quitting and relapse prevention were also mailed to participants to share with other smokers.

\section{Eligibility and Screening}

Interested individuals contacted us by telephone or in-person. Study staff provided smokers with detailed information about the study and offered screening for eligibility. To be eligible, individuals self-identified as African-American, were age 18 or older, interested in stopping smoking, smoked $\leq 10 \mathrm{cpd}$ for $\geq 2$ years, smoked on $\geq 25$ days in the past month, and were willing to attend 4 clinic visits over the course of 6 months. They must have smoked for at least 3 years, have a home address and a functioning telephone number. Exclusion criteria included current use of bupropion; use of psychoactive medications; use of nicotine replacement therapy, fluoxetine, clonidine, buspirone, or doxepin in the past 30 days; history of alcohol or substance abuse within the past year; current drinking of 14 or more alcoholic drinks per week and/or binge drinking (5 or more drinks on one occasion) 2 or more times in the past month; history of seizures or head trauma; history of bulimia or anorexia nervosa; pregnant (verified by over the counter pregnancy test kit for women of child-bearing age only) or contemplating pregnancy; breast feeding; myocardial infarction in the past 30 days; use of other forms of tobacco in the past 30 days; reported use of opiates, cocaine, or stimulants; diabetes treated with oral hypoglycemics or insulin; planning to move from the Kansas City metro area in the next
12 months; and having another smoker in the household enrolled in the study.

\section{Consent and Randomization}

Study staff reviewed procedures with individuals who were eligible to participate in the study and administered written informed consent to these individuals at the baseline visit. As part of the consent process, potential participants were informed about mandatory collection of blood samples for DNA analysis and procedures for collecting and handling of the samples. Study staff explained the rationale for the genetic analysis, i.e. to understand individual differences in nicotine and bupropion metabolism and smoking behavior among African-American smokers, and how these factors influenced the likelihood of successfully stopping smoking. The consent form specified that (a) analysis of DNA "cannot and will not be used for my own benefit and no results, even if unfavorable, will be forwarded to me," (b) DNA would be stored for a period of no less than 10 years, (c) participants could request at any time that their DNA be destroyed, (d) while results of the study may be published, no identifying information would be included in publications and confidentiality would be maintained, and (e) blood samples would not be used to develop a commercial product. Participants responded yes or no to the question, "I give permission for my DNA to be used in future studies about smoking." Participants also were asked for permission to be contacted for future studies that might require additional information. A computer generated random numbers table was used to randomize participants into an active bupropion and health education (HE) counseling (Tx) condition or to a placebo and HE counseling (C) condition. Both participants and investigators were blinded to the pharmacotherapy condition.

\section{Intervention}

Participants received pharmacotherapy treatment (bupropion or placebo) for 7 weeks, health education (HE) counseling through Week 16, and were followed through Week 26. All participants received Kick It at Swope: Stop Smoking Guide, a culturally sensitive smoking cessation guide developed for African American light smokers and used previously [22].

\section{Bupropion}

At baseline (Week 0), a research assistant gave each participant a 7-week supply of bupropion SR $150 \mathrm{mg}$ (150 $\mathrm{mg}$ daily for 3 days, then $150 \mathrm{mg}$ twice daily) or placebo. All participants received an instruction sheet on effective use of bupropion. A scheduled quit date was planned to follow 7 days of pharmacotherapy use. Adverse events were assessed at Weeks 1, 3, 5, 7, and 16. Serum levels of bupropion were drawn at Week 3 for measurement of concentrations of bupropion and metabolites. 


\section{Counseling}

Health Education (HE) counseling is an education-based intervention that incorporates recommendations from the current tobacco treatment guidelines: giving clear advice to stop smoking, providing assistance with quitting, and arranging follow-up [18]. In this study, HE counseling included providing information about the risks of continued smoking and the benefits of quitting, developing a quit plan, outlining a concrete quit day preparation plan, discussing strategies for successful quitting, building social support, reducing stress, recognizing and managing withdrawal and craving, overcoming barriers to abstinence, and using pharmacotherapy. Table 1 provides a description of the six HE sessions provided to participants in both arms of the study in person at Weeks $0,1,3,7$, and by phone at Weeks 5 and 16. Study staff used semi-structured scripts for HE sessions to incorporate counseling with use of the Kick It at Swope: Stop Smoking Guide, but worked to tailor information to the individual while assisting participants in developing personalized stop smoking plans. HE sessions lasted, on average, 15-20 minutes.

\section{Written materials}

At baseline, study staff reviewed the Kick It at Swope Stop Smoking Guide with participants. The 36-page guide includes information about health consequences of tobacco use and benefits of quitting, disproportionate effects of tobacco on African-American smokers, menthol, light smoking and related risks. Specific strategies to promote abstinence included making a quit plan, using medication, obtaining social support, managing withdrawal and craving, exercise and healthy eating, coping with a lapse and relapse prevention.

Retention Prior to each study visit, study staff completed telephone calls and sent postcard to all participants of scheduled appointments. For any missed session, participants received up to 6 telephone calls to facilitate rescheduling. Study staff gave each participant a $\$ 20$ gift card for completing each in person visit (Weeks $0,3,7$ ) and a $\$ 40$ card for completing follow-up at Week 26, in appreciation of participant time and effort. Remuneration was based on session attendance and not on smoking status. Staff also distributed small tokens (e.g., tote bag, t-shirt, museum passes) to participants for in person and telephone sessions completed throughout the study.

\section{Measures}

Table 2 provides an overview of assessments conducted over the course of KIS-III. Study staff verbally administered all self-report measures.

\section{Demographic measures}

Demographic information during the baseline assessment was collected using standardized questionnaires. This information included age, gender, marital status, income, employment status and education. Height and weight were measured to calculate body mass index.

\section{Smoking behavior measures}

Baseline assessment of smoking history included current number of cigarettes smoked per day (CPD), type of cigarette smoked (menthol or non-menthol), age when first smoked, age when started smoking regularly, quitting and relapse history, reason for most recent relapse, and implementation of home smoking restrictions. Timeline follow back [32] was employed to assess individual patterns of smoking over the past week. Participants rated motivation and confidence for quitting on a ten point scale, with higher scores reflecting greater motivation or confidence. Nicotine dependence was measured using the Fagerström Test of Nicotine Dependence (FTND) [33] and the Wisconsin Inventory of Smoking Dependence Motives, 30 items (WISDM-30) [34-36]. Nicotine withdrawal in the

Table 1 Overview of Health Education Counseling Sessions

\begin{tabular}{|c|c|c|}
\hline Session Number & Goal & Topic \\
\hline $\begin{array}{l}\text { Randomization, Week } \\
0 \text { (30 minutes) }\end{array}$ & $\begin{array}{l}\text { Establish rapport with participant-emphasizing willingness } \\
\text { to help them quit and encouraging their motivation/ } \\
\text { confidence to quit smoking. }\end{array}$ & $\begin{array}{l}\text { AA tobacco use, health risks, benefits of quitting, learning from } \\
\text { past quit attempts; and developing a plan for quit day. } \\
\text { Instructions of medication use as well as Identifying triggers } \\
\text { and managing withdrawal were also reviewed }\end{array}$ \\
\hline Week 1 (15 minutes) & $\begin{array}{l}\text { Reinforce quit day plan, address medication use, identify } \\
\text { concerns, barriers, and strategies for success }\end{array}$ & $\begin{array}{l}\text { If Quit: Rewarding yourself, recovering from slip, review } \\
\text { medication use or ending medication (week 7), managing } \\
\text { stress, alternatives to smoking, identify barriers, and living } \\
\text { smoke-free }\end{array}$ \\
\hline Week 3 (20 minutes) & $\begin{array}{l}\text { Reinforce and encourage abstinence efforts. Identify } \\
\text { concerns, barriers, and strategies for successes }\end{array}$ & \\
\hline \multicolumn{3}{|l|}{ Week 5 (15 minutes) } \\
\hline \multicolumn{3}{|l|}{ Week 7 (20 minutes) } \\
\hline Week 16 (15 minutes) & & $\begin{array}{l}\text { If still smoking: Review reasons for not quitting, review } \\
\text { reasons for quitting, discuss specific problems that lead to } \\
\text { relapse, and attempt to set a new quit plan }\end{array}$ \\
\hline
\end{tabular}


Table 2 KIS III Assessments

\begin{tabular}{|c|c|c|c|c|c|c|c|c|c|c|}
\hline Assessment & $\begin{array}{c}\# \\
\text { items }\end{array}$ & $\begin{array}{l}\text { Ranges of } \\
\text { Scores }\end{array}$ & Eligibility & $\begin{array}{l}\text { Randomization } \\
\text { Week } 0\end{array}$ & $\begin{array}{c}\text { Week } \\
1\end{array}$ & $\begin{array}{c}\text { Week } \\
3\end{array}$ & $\begin{array}{l}\text { Week } \\
5\end{array}$ & $\begin{array}{c}\text { Week } \\
7\end{array}$ & $\begin{array}{c}\text { Week } \\
16\end{array}$ & $\begin{array}{c}\text { Week } \\
26\end{array}$ \\
\hline Blood draw & & & & $x$ & & $x$ & & & & \\
\hline Salivary cotinine & & & & & & & & & & $x$ \\
\hline Demographics & 7 & & $x$ & $x$ & & & & & & \\
\hline Cigarette Data & 5 & & & $x$ & & & & & & \\
\hline Other Tobacco Use & 1 & & $x$ & $x$ & & & & $x$ & & $x$ \\
\hline Smoking Status (cpd) & 1 & & $x$ & $x$ & $x$ & $x$ & & $x$ & & $x$ \\
\hline Timeline Follow-back (TLFB) & 7 & & & $x$ & & $x$ & & $x$ & & $x$ \\
\hline Smoking History & 4 & & & $x$ & & & & & & \\
\hline Quitting History & 4 & & & $x$ & & & & & & \\
\hline \multicolumn{11}{|l|}{ Weight Concerns: } \\
\hline Weight Concerns Scale, & 6 & $1-6$ & & & & & & & & \\
\hline Weight Self Efficacy Scale, & 6 & $1-10$ & & $x$ & & & & & & \\
\hline Adapted Myers Weight Concerns & 2 & $0-11$ & & & & & & & & \\
\hline Home Smoking Restrictions & 5 & & & $x$ & & & & $x$ & & \\
\hline Work Place Smoking Restrictions & 4 & & & $x$ & & & & & & \\
\hline Motivation to Quit & 1 & $1-10$ & & $x$ & & & & & & \\
\hline Confidence to Quit & 1 & $1-10$ & & $x$ & & & & & & \\
\hline Nicotine Dependence (FTND) & 6 & $0-10$ & & $x$ & & & & & & \\
\hline $\begin{array}{l}\text { Wisconsin Inventory of Smoking Dependence } \\
\text { Motives (WISDM-30) }\end{array}$ & 30 & $10-70$ & & $x$ & & & & & & \\
\hline Minnesota Withdrawal Scale (MNWS) & 8 & $0-32$ & & $x$ & & $x$ & & $x$ & & $x$ \\
\hline$\overline{\text { Craving (QSU-Brief) }}$ & 10 & $1-7$ & & $x$ & & $x$ & & $x$ & & $x$ \\
\hline Positive and Negative Affect (PANAS) & 20 & $10-50$ & & $x$ & & $x$ & & $x$ & & $x$ \\
\hline \multicolumn{11}{|l|}{ Depression: } \\
\hline CES-Short Depression Scale (CESD-10), & 10 & $0-30$ & & & & & & & & \\
\hline 2-item Patient Health Questionnaire (PHQ-2) & 2 & $0-6$ & & $x$ & & $x$ & & $x$ & & $x$ \\
\hline Stress (PSS-4) & 4 & $0-16$ & & $x$ & & & & & & \\
\hline Social Support (ISEL-12) & 12 & $12-48$ & & $x$ & & & & & & \\
\hline Impulsivity & 5 & $5-20$ & & $x$ & & & & & & \\
\hline \multirow[t]{2}{*}{ Racial Discrimination [45] } & 12 & $0-9$ & & $x$ & & & & & & \\
\hline & & $0-45$ & & & & & & & & \\
\hline Racial/Ethnic Identity & 8 & & & $x$ & & & & & & \\
\hline Approximate duration of survey (in minutes) & & & 10 & 45 & 5 & 15 & 5 & 15 & 5 & 10 \\
\hline
\end{tabular}

past 24-hours was assessed using the Minnesota Nicotine Withdrawal Scale (MNWS) [37]. The brief version of the Questionnaire for Smoking Urges (QSU-brief) assessed craving to smoke [38].

\section{Psychosocial measures}

The Center for Epidemiologic Studies Short Depression Scale (CESD-10) assessed distress associated with depressive symptoms [39,40]. The 2-item Patient Health Questionnaire (PHQ-2) was also used to identify primary symptoms of depression over the past two weeks [41]. The Perceived Stress Scale, 4 items (PSS-4) assessed selfappraised stress experienced in the past month [42]. The 12-item Interpersonal Support Evaluation List (ISEL-12) assessed global level of social support [43]. The Positive and Negative Affect Scales (PANAS) were administered to measure positive (e.g., alert, enthusiastic) and negative (e.g., anger, fear) affective states [44]. We used the Experiences of Discrimination (EOD) scale to assess the frequency of self-reported discrimination because of race, ethnicity or color $[45,46]$. The Reward Responsiveness Scale of the Behavioral Inhibition System/Behavioral Activation Scale (BIS/BAS) assessed behavioral inhibition, behavioral activation, and affective responses to impending reward and punishment [47]. Smoking-related weight concerns and confidence to maintain current weight after quitting were assessed using the Meyers Weight Concerns 
Scale [48], a modified version of the Weight Concerns Scale [49], and the Weight Efficacy After Quitting scale (WEAQ) [49].

\section{Biochemical measures \\ Nicotine metabolism phenotype (3HC/COT ratio) and genotype}

Cytochrome P450 (CYP) 2A6 is the major enzyme responsible for metabolizing nicotine into cotinine (COT) and the further metabolism of COT to trans-3'hydroxycotinine $(3 \mathrm{HC})[50,51]$. Cotinine, in turn, is metabolized into trans-3'-hydroxycotinine $(3 \mathrm{HC})$ also by CYP2A6 [51]. The half-life of nicotine (2 hours) is relatively short compared to cotinine (16 hours) [52]. Trans-3'-hydroxycotinine (3HC) is formation dependent, resulting in a half life that is the same as its parent cotinine (16 hours). Therefore, the ratio of $3 \mathrm{HC}$ to cotinine is fairly constant over time [53]. The plasma $3 \mathrm{HC} / \mathrm{COT}$ ratio is highly correlated with total nicotine clearance and CYP2A6 activity making it a useful biomarker of the rate of nicotine metabolism [54]. Both the $3 \mathrm{HC} /$ COT ratio and/or CYP2A6 genotype have been associated with the number of cigarettes smoked per day and the likelihood of quitting $[27,55,56]$, although disparate findings suggest further study is needed particularly among different racial/ethnic groups [57-60].

\section{Bupropion metabolism phenotype and genotype}

Bupropion acts, in part, by inhibiting norepinephrine and dopamine reuptake [61]. Bupropion has three principal metabolites: hydroxybupropion, threohydrobupropion, and erythrohydrobupropion [62]. The mean elimination half-lives for these metabolites are estimated to be 20 hours for hydroxybupropion, 37 hours for threohydrobupropion, and 33 hours for erythrohydrobupropion. These metabolites are known to be pharmacologically active, although their relative activity is not well established [29]. Following $150 \mathrm{mg}$ of sustainedrelease bupropion every 12 hours, steady state plasma concentrations for bupropion and metabolites are reached within 8 days.

CYP2B6 metabolizes bupropion to its main metabolite 6 -hydroxybupropion $[63,64]$. Genetic variation of CYP2B6 alters enzyme activity [30,65-68], and genetic variation in CYP2B6 has been associated with differences in smoking cessation outcomes [30].

\section{Blood and Serum Collection}

Blood samples were collected at two time points: Weeks 0 and 3. Samples were collected at Week 0 for evaluation of nicotine metabolism phenotype $(3 \mathrm{HC} / \mathrm{COT}$, derived from nicotine from smoking) and both CYP2A6 and CYP2B6 genotype. Participants smoked one cigarette of their usual brand: after 30 minutes, $20 \mathrm{ml}$ of blood was drawn into polypropylene containers- B-D vacutainer containing 100 USP units Lithium Heparin, mixed by inversion and centrifuged at room temperature for 10-15 minutes. Plasma was extracted and stored at $-20^{\circ} \mathrm{C}$. Following completion of data collection, plasma samples will be thawed at room temperature and then assayed by solid phase extraction followed by LC/MS/ MS [69] to evaluate nicotine, COT and 3HC using standard procedures [70,71]. For genotyping, $20 \mathrm{mls}$ of blood was collected into ACD tubes, mixed and then transferred samples to $20 \mathrm{ml}$ plastic scintillation vials which were frozen at $-20^{\circ} \mathrm{C}$. CYP2A6 and $C Y P 2 B 6$ genotyping will use published gene and allele-specific polymerase chain reaction assays $[4,31,51]$.

Week 3 was selected as the time point for the analysis of bupropion metabolism phenotype, as participants using active bupropion $(\mathrm{n}=270)$ will have 1$)$ reached steady state levels of bupropion, and 2) passed at least 7 days from their Quit Date, allowing us to evaluate bupropion metabolism in relation to cotinine-confirmed 7-day point prevalence abstinence. Because participants and study staff were blinded to treatment condition, blood was collected from all participants. Participants reported the date and time of their most recent medication dose and their daily use of study medication during the previous 7 days, and the information were recorded in relation to the date and time of blood draw. Following completion of all participant data collection, followup, and subsequent unblinding of randomization, phenotype analysis will be conducted for samples of participants from the active bupropion arm of the study only.

\section{Salivary cotinine validation of smoking abstinence}

The primary endpoint of this study is biochemically verified 7-day point prevalence smoking abstinence defined as no cigarettes (not even a puff) in the previous 7 days at Week 26, validated using salivary cotinine collected at Week 26. This method is consistent with recommended guidelines [72,73]. We used the cut-point of $15 \mathrm{ng} / \mathrm{ml}$ cotinine to differentiate smokers from nonsmokers [73-75]. Salivary cotinine analysis was conducted using gas chromatography technique as described elsewhere [76].

\section{Data analysis}

Within this paper, we calculated descriptive summaries of baseline (Week 0) demographic, psychosocial characteristics and smoking history of the participants using frequencies and percentages for categorical variables and means and standard deviations for quantitative variables. Phenotyping, genotyping, and evaluation of abstinence outcomes will be presented in future manuscripts.

\section{Results}

An overview of screening and enrollment for KIS-III is provided in Figure 1. Of 2,628 individuals who 
expressed interest in study participation and were screened for eligibility, 999 (38\%) were phone-eligible and were scheduled for in-person screening. Radio was the most common source of information about the study (29\%), followed by recruitment through the Swope clinic (20\%), television (17\%), word of mouth (13\%), and Truman Medical Center (9\%). Most of those screened (70\%) were ineligible for study participation with the primary reasons for ineligibility being smoking $>10 \mathrm{CPD}$, not medically eligible, use of other forms of tobacco, and binge drinking within the past 6 months. Of smokers who passed phone eligibility, one third (370) did not keep the final eligibility study appointment. Of those who attended final eligibility screening (629), 89 (14\%) were not eligible for randomization. Five hundred and forty (86\% of those attending final eligibility screening) were eligible, consented, and randomized to the bupropion or placebo treatment group.

Participant randomization by month (from December 2007 to October 2009) is presented in Figure 2. The bar graph represents monthly numbers of individuals screened, those ineligible, those who did not keep appointment and participants randomized, while the line graph reflects cumulative enrolment over the study period. Participant enrollment was completed 7 weeks ahead of the projected schedule.

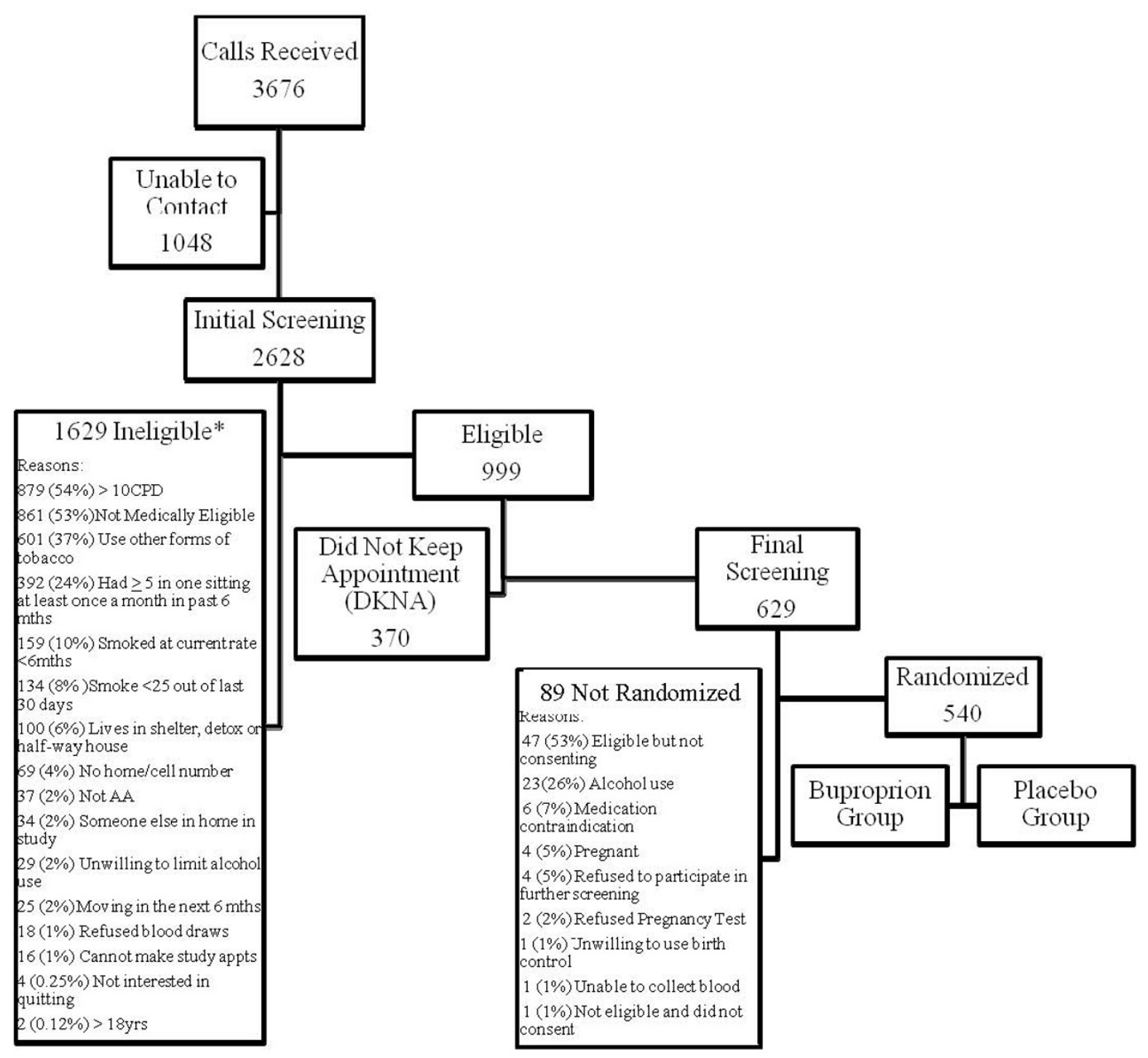

*People may be ineligible for more than one reason.

Figure 1 Screening and enrollment of study participants 


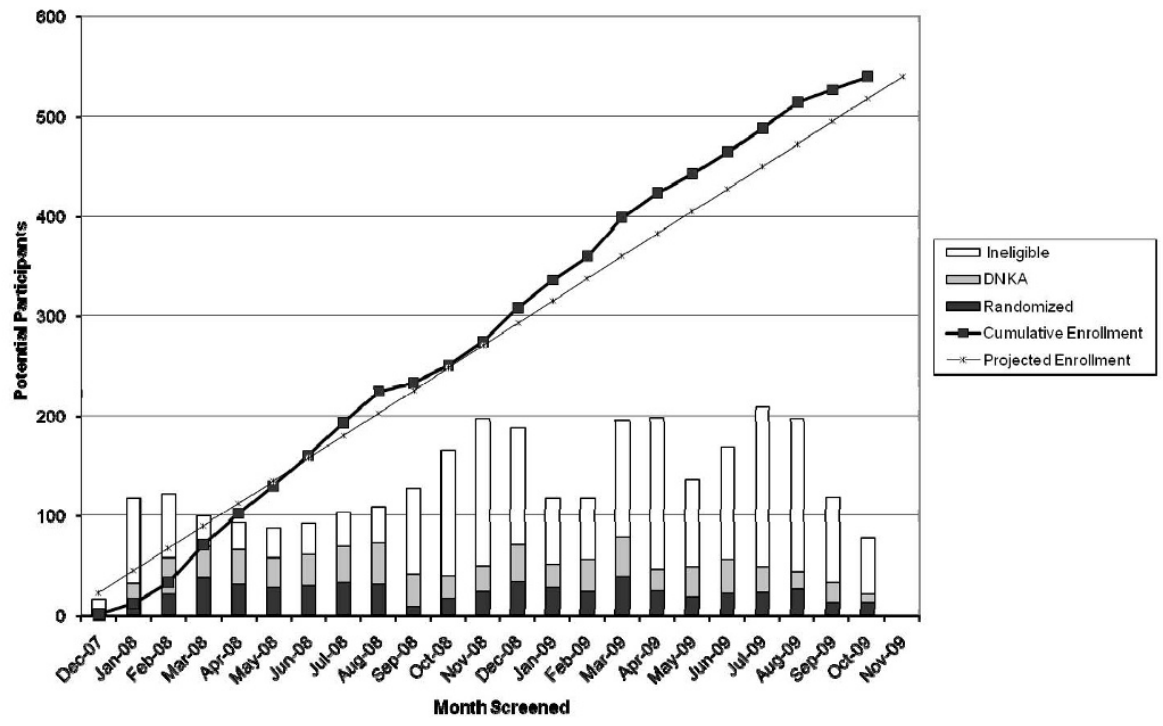

Figure 2 Cumulative Enrollment and Number of Randomized, Those Who Did Not Keep Their Appointment (DNKA), and Ineligible Participants.

Table 3 Participant Characteristics

\begin{tabular}{|c|c|c|}
\hline & Summary statistics & Sample size $(\mathrm{n})$ \\
\hline \multicolumn{3}{|l|}{ Demographic Variables } \\
\hline Age, mean $[S D]$ yr & $46.5(11.3)$ & 540 \\
\hline Women, n (\%) & $357(66.1)$ & 540 \\
\hline Married or living with partner, n (\%) & $166(30.8)$ & 539 \\
\hline Monthly family income < \$1800, n (\%) & $327(60.7)$ & 539 \\
\hline Education $\geq$ High school, n (\%) & $454(84.2)$ & 539 \\
\hline Weight, mean [SD] & $195.5(52.9)$ & 539 \\
\hline BMI, mean [SD] & $31.1(7.9)$ & 539 \\
\hline \multicolumn{3}{|l|}{ Psychosocial Variables } \\
\hline Depression (CESD-10), mean [SD] & $7.7(5.2)$ & 539 \\
\hline Stress (PSS-4), mean [SD] & $5.2(3.2)$ & 539 \\
\hline \multicolumn{3}{|l|}{ Tobacco Related Variables } \\
\hline Serum cotinine in ng/ml., mean [SD] & $275.8(155.8)$ & 536 \\
\hline Exhaled carbon monoxide in p.p.m., mean [SD] & $16.4(10.0)$ & 411 \\
\hline Cigarettes per day, mean [SD] & $8.0(2.5)$ & 540 \\
\hline Time to first cigarette, $\leq 30$ minutes, n (\%) & $390(72.2)$ & 540 \\
\hline FTND, mean [SD] & $3.2(1.7)$ & 540 \\
\hline Smoke menthol cigarettes, n (\%) & $452(83.7)$ & 540 \\
\hline Number of previous 24 hour quit attempts in the past year, mean [SD] & $3.7(7.7)$ & 540 \\
\hline Use of pharmacotherapy during the most recent quit attempt, n (\%) & $133(24.2)$ & 511 \\
\hline Age of first cigarette, mean [SD] yr & $17.6(5.9)$ & 538 \\
\hline Age started smoking regularly, mean [SD] & $21.1(7.1)$ & 538 \\
\hline Motivation to quit, mean [SD] & $9.7(0.8)$ & 540 \\
\hline Confidence to quit, mean [SD] & $7.9(2.4)$ & 540 \\
\hline Smoke-free household, n (\%) & $132(24.4)$ & 540 \\
\hline
\end{tabular}


Table 3 presents baseline characteristics of KIS-III study participants. Participants had a mean age of 46.5 years, the majority, (66.1\%) were women, one in three were married or living with a partner, and over $84 \%$ had obtained a high school degree. Almost two in three earned less than $\$ 1,800$ monthly. Participants smoked an average of 8.0 cigarettes per day, had a mean exhaled carbon monoxide of $16.4 \mathrm{ppm}$ with a range of (1-55), a mean cotinine of $275.8 \mathrm{ng} / \mathrm{ml}$. Mean Body Mass Index (BMI) was 31.1. Over 72\% smoked within 30 minutes of waking with a mean FTND dependence score of 3.2 with a range of (0-7). Most $(83.7 \%)$ reported smoking menthol cigarettes. Only $24.4 \%$ reported living in a smoke-free household. The average number of quit attempts in the past year was 3.7 and $24.2 \%$ reported using pharmacotherapy during their most recent quit attempts. Motivation and confidence to quit were high. These demographic and smoking history characteristics are similar to African American light smokers from our previous KIS-II trial [22].

Retention of participants for Weeks 1, 3, 5, 7, 16, and 26 was $90.6 \%, 78.7 \%, 75.7 \%, 72.8 \%, 67.6 \%$, and $70.2 \%$, respectively. Of six total counseling sessions, participants completed a mean (SD) of 4.85 (1.49) sessions.

\section{Discussion}

The Kick It at Swope III (KIS-III) trial was designed as the first treatment study of bupropion for African American light smokers. To date, KIS-III is the fourth study to evaluate pharmacotherapy for light smokers $[22,77,78]$ and the second to evaluate treatment for African American light smokers [22]. KIS-III is also the first study to examine both nicotine and bupropion metabolism, evaluating CYP2A6 and CYP2B6 phenotype and genotype as possible predictors of outcome, within the context of treatment of African American smokers. Collecting data on metabolism and genotype allows us to evaluate biological mechanisms in conjunction with psychosocial and smoking data to further advance our understanding of African American smoking behavior and ultimately enhance treatment outcomes.

We have demonstrated the feasibility of recruiting and enrolling African American light smokers into a clinical treatment trial involving biological data collection and genetic analysis. These feasibility findings are consistent with studies that have successfully enrolled African American smokers for treatment and provide further evidence of willingness to share genetic information within a research study of smoking behavior [19,79]. KIS-II enrolled smokers into a cessation trial but conducted the genetic portion of the study using a second consent process. In KIS-II, there was $83 \%$ participation in the genetic portion of the study [79]. Based in part on this excellent consent rate, indicating consent for genetic analysis posed little barrier to enrollment, KIS-III included genetic analysis as part of overall study participation and enrolled accordingly. Participants were informed during screening about the goals of the study, the requirement of multiple collections of biological samples, and the rationale for collecting such data. This information was reviewed in further detail within the consent process. Of 1629 individuals who completed any screening for study participation, only 18 (1.1\%) were ineligible to participate in the study because they refused blood draws, suggesting that the inclusion of phenotype and genotype assessments did not impede recruitment in this African American population. Factors that contributed to recruitment success may include conducting this research within a trusted community medical setting, having an established history of smoking cessation treatment and research within the community, and using a multi-method approach to recruitment. The current data add to the literature demonstrating support for inclusion of African American smokers in smoking cessation treatment studies, in genetic investigation of tobacco use and treatment, and more broadly in cancer control research.

Consistent with our previous KIS trials, study participants were largely low income and predominantly menthol cigarette smokers. Despite excluding individuals currently using pharmacotherapy for the treatment of depression, we found approximately one third of participants reported symptoms of depression. As other research has shown bupropion to reduce negative mood during smoking cessation treatment $[80,81]$ and to be effective in supporting abstinence in moderate to heavy smokers with or without a history of depression [82], we are planning analyses examining changes in mood and depression in relation to smoking behavior within the current sample of African American light smokers. Importantly, while low income, use of menthol, and depression previously have been associated with poorer smoking cessation treatment outcomes [21,83-87], this sample was highly motivated to stop smoking. Our previous KIS-II trial found health education counseling contributed to higher rates of abstinence in highly motivated African American light smokers, when compared to motivational counseling [22]. The finding that smokers in the current trial show similarly high levels of motivation provided support for the use of health education counseling within the current study.

Examination of KIS-III screening data points to some limitations related to generalizability and recommendations for needed research. Over half of individuals who expressed interest in enrolling in this smoking cessation study were ineligible to use bupropion according to study protocol. Future research should examine other pharmacotherapy for light smokers, such as varenicline, which has been found to be effective in moderate to 
heavy smokers ( $>10 \mathrm{cpd})$ [18]. Findings also showed over one third of interested smokers screened in KIS-III reported use of other forms of tobacco and were excluded from treatment. While smoking cessation clinical trials typically exclude smokers who report use of other forms of tobacco, future studies may provide greater generalizability by examining tobacco use treatment more broadly defined. Inclusion of smokers who use other forms of tobacco would require consideration of appropriate measures of tobacco use and abstinence verification.

In summary, the KIS-III study provides a unique opportunity to evaluate psychosocial and biological mechanisms related to drug use and treatment outcomes in African-American light smokers. Baseline findings support the feasibility of enrolling African American light smokers in a treatment study involving genetic analysis. Identifying individuals for whom treatments are most effective and, in contrast, identify characteristics related to relapse risk will contribute to advancing tailored tobacco use treatment, with the ultimate goal of enhancing treatment and reducing tobacco-related health disparities for African-American smokers.

\footnotetext{
Acknowledgements

The authors would like to thank the staff at Swope Health Central, as well as Olivia Chang, Emily Kravit, Jennifer Lipari, Ian Lynam, Heather Newhard, Terri Tapp and Cinnamon Smith for their efforts on this project. We thank Rebecca Clausius for assistance in manuscript preparation. We also are grateful to the volunteers who participated in this research.

Funding

This research is supported by the National Cancer Institute at the National Institutes of Health (R01CA091912 and R01CA091912-09S1). Dr. Ahluwalia is supported in part by the National Institute for Minority Health and Disparities (NIMHD/NIH - 1P60MD003422). Dr. Tyndale is supported by $\mathrm{CAMH}$ and by a Canada Research Chair in Pharmacogenetics.
}

\section{Author details}

${ }^{1}$ Department of Preventive Medicine and Public Health, University of Kansas Medical Center, Kansas City, KS, USA. ${ }^{2}$ Department of Biostatistics, University of Kansas Medical Center, Kansas City, KS, USA. ${ }^{3}$ Department of Family Medicine and Community Health, University of Minnesota Medical School, Minneapolis, MN, USA. ${ }^{4}$ Program in Health Disparities Research, University of Minnesota Medical School, Minneapolis, MN, USA. ${ }^{5}$ University of MissouriKansas City School of Medicine, Kansas City, MO, USA. ${ }^{6}$ Division of Clinical Pharmacology and Experimental Therapeutics, Department of Medicine and Bioengineering \& Therapeutic Sciences, University of California, San Francisco, CA USA. ${ }^{7}$ Center for Addiction and Mental Health and Departments of Psychiatry and Pharmacology, University of Toronto, Toronto, ON, Canada. ${ }^{8}$ Department of Medicine, University of Minnesota Medical School, Minneapolis, MN, USA. ${ }^{9}$ Center for Health Equity, University of Minnesota Medical School, Minnespolis, MN, USA.

\section{Authors' contributions}

LSC, MSM, NLN, WSC, KSO, NLB, RFT, JSA contributed to the concept and design, acquisition of data, interpretation of data, and drafting of manuscript. BF, RB, and TSS, contributed to acquisition of data, data analysis, interpretation of data and drafting of manuscript. CAB and GAS contributed to acquisition of data. All authors read and approved the final manuscript.

\section{Competing interests}

Dr. Ahluwalia serves as a consultant to Pfizer Pharmaceuticals, Inc. Dr. Benowitz serves as a consultant to Pfizer Pharmaceuticals, Inc. and has been a paid expert witness in litigation against tobacco companies. Dr. Tyndale holds shares in Nicogen Research Inc., a company that is focused on novel smoking cessation treatment approaches: no Nicogen funds were used in this work.

Received: 20 August 2010 Accepted: 25 January 2011

Published: 25 January 2011

\section{References}

1. ACS: Cancer Facts and Figures 2009 Atlanta; 2009.

2. Fu S, Kodl M, Joseph A, Hatsukami D, Johnson E, Wu B, Bierut L: Racial/ Ethnic disparities in the use of nicotine replacement therapy and quit ratios in lifetime smokers ages 25 to 44 years. Cancer Epidemiol Biomarkers Prev 2008, 17:1640-1647.

3. Fagan P, Moolchan ET, Lawrence D, Fernander A, Ponder PK: Identifying health disparities across the tobacco continuum. Addiction 2007, 102(Suppl 2):5-29.

4. Ho MK, Faseru B, Choi WS, Nollen NL, Mayo MS, Thomas JL, Okuyemi KS, Ahluwalia JS, Benowitz NL, Tyndale RF: Utility and relationships of biomarkers of smoking in African-American light smokers. Cancer Epidemiol Biomarkers Prev 2009, 18:3426-3434.

5. King G, Polednak A, Bendel RB, Vilsaint MC, Nahata SB: Disparities in smoking cessation between African Americans and Whites: 1990-2000. Am J Public Health 2004, 94:1965-1971.

6. Okuyemi KS, Ahluwalia JS, Banks R, Harris KJ, Mosier MC, Nazir N, Powell J: Differences in smoking and quitting experiences by levels of smoking among African Americans. Ethn Dis 2004, 14:127-133.

7. Shiffman S, Brockwell SE, Pillitteri JL, Gitchell JG: Use of smoking-cessation treatments in the United States. Am J Prev Med 2008, 34:102-111.

8. Lawrence D, Fagan P, Backinger CL, Gibson JT, Hartman A: Cigarette smoking patterns among young adults aged 18-24 years in the United States. Nicotine Tob Res 2007, 9:687-697.

9. Haiman CA, Stram DO, Wilkens LR, Pike MC, Kolonel LN, Henderson BE, Le Marchand L: Ethnic and racial differences in the smoking-related risk of lung cancer. N Engl J Med 2006, 354:333-342.

10. Trinidad DR, Perez-Stable EJ, Emery SL, White MM, Grana RA, Messer KS: Intermittent and light daily smoking across racial/ethnic groups in the United States. Nicotine Tob Res 2009, 11:203-210.

11. USDHHS: Tobacco use among U.S. racial ethnic minority groups African Americans, American Indians, and Alaskan Natives, Asian Americans, and Pacific Islanders and Hispanics: a report of the surgeon general Atlanta: Department of Health and Human Services, Centers for Disease Control and Prevention, National Center for Chronic Disease Prevention and Health Promotion, Office on Smoking and Health; 1998.

12. Allen B Jr, Unger JB: Sociocultural correlates of menthol cigarette smoking among adult African Americans in Los Angeles. Nicotine Tob Res 2007, 9:447-451.

13. Castro FG: Physiological, psychological, social, and cultural influences on the use of menthol cigarettes among Blacks and Hispanics. Nicotine Tob Res 2004, 6(Suppl 1):S29-41.

14. Patterson F, Benowitz $N$, Shields $P$, Kaufmann V, Jepson C, Wileyto $P$, Kucharski S, Lerman C: Individual differences in nicotine intake per cigarette. Cancer Epidemiol Biomarkers Prev 2003, 12:468-471.

15. Ho MK, Mwenifumbo JC, Al Koudsi N, Okuyemi KS, Ahluwalia JS, Benowitz NL, Tyndale RF: Association of nicotine metabolite ratio and CYP2A6 genotype with smoking cessation treatment in AfricanAmerican light smokers. Clin Pharmacol Ther 2009, 85:635-643.

16. Benowitz NL, Bernert JT, Caraballo RS, Holiday DB, Wang J: Optimal serum cotinine levels for distinguishing cigarette smokers and nonsmokers within different racial/ethnic groups in the United States between 1999 and 2004. Am J Epidemiol 2009, 169:236-248.

17. Benowitz NL, Perez-Stable EJ, Fong I, Modin G, Herrera B, Jacob P: Ethnic differences in N-glucuronidation of nicotine and cotinine. J Pharmacol Exp Ther 1999, 291:1196-1203.

18. Fiore MC, Jaen CR, Baker TB, Bailey WC, Benowitz NL, Curry SJ, Dorfman SF, Froelicher ES, Goldstein MG, Healton CG, Henderson PN, Heyman RB, Koh HK, Kottke TE, Lando HA, Mecklenburg RE, Mermelstein RJ, Mullen PD, Orleans CT, Robinson L, Stitzer ML, Tommasello AC, Villejo L, Wewers ME: Treating Tobacco Use and Dependence: 2008 Update. Clinical Practice Guideline Rockville: U.S. Department of Health and Human Services, Public Health Service; 2008. 
19. Cox LS, Okuyemi K, Choi WS, Ahluwalia JS: A review of tobacco use treatments in U.S. ethnic minority populations. Am J Health Promot 2011.

20. Ahluwalia JS, Harris KJ, Catley D, Okuyemi KS, Mayo MS: Sustained-release bupropion for smoking cessation in African Americans: a randomized controlled trial. JAMA 2002, 288:468-474.

21. Okuyemi KS, Cox LS, Nollen NL, Snow TM, Kaur H, Choi W, Nazir N, Mayo MS, Ahluwalia JS: Baseline characteristics and recruitment strategies in a randomized clinical trial of African-American light smokers. Am J Health Promot 2007, 21:183-191.

22. Ahluwalia JS, Okuyemi K, Nollen N, Choi WS, Kaur H, Pulvers K, Mayo MS: The effects of nicotine gum and counseling among African American light smokers: A $2 \times 2$ factorial design. Addiction 2006, 101:883-891.

23. Benowitz NL: Smoking cessation trials targeted to racial and economic minority groups. JAMA 2002, 288:497-499.

24. Malaiyandi V, Sellers EM, Tyndale RF: Implications of CYP2A6 genetic variation for smoking behaviors and nicotine dependence. Clin Pharmacol Ther 2005, 77:145-158.

25. Tyndale RF, Sellers EM: Genetic variation in CYP2A6-mediated nicotine metabolism alters smoking behavior. Ther Drug Monit 2002, 24:163-171.

26. Patterson F, Schnoll RA, Wileyto EP, Pinto A, Epstein LH, Shields PG, Hawk LW, Tyndale RF, Benowitz N, Lerman C: Toward personalized therapy for smoking cessation: a randomized placebo-controlled trial of bupropion. Clin Pharmacol Ther 2008, 84:320-325.

27. Schoedel KA, Hoffmann EB, Rao Y, Sellers EM, Tyndale RF: Ethnic variation in CYP2A6 and association of genetically slow nicotine metabolism and smoking in adult Caucasians. Pharmacogenetics 2004, 14:615-626.

28. Lerman C, Jepson C, Wileyto EP, Patterson F, Schnoll R, Mroziewicz M, Benowitz N, Tyndale RF: Genetic variation in nicotine metabolism predicts the efficacy of extended-duration transdermal nicotine therapy. Clin Pharmacol Ther 2010, 87:553-557.

29. Johnston JA, Fiedler-Kelly J, Glover ED, Sachs DP, Grasela TH, DeVeaughGeiss J: Relationship between drug exposure and the efficacy and safety of bupropion sustained release for smoking cessation. Nicotine Tob Res 2001, 3:131-140

30. Lerman C, Shields PG, Wileyto EP, Audrain J, Pinto A, Hawk L, Krishnan S, Niaura R, Epstein L: Pharmacogenetic investigation of smoking cessation treatment. Pharmacogenetics 2002, 12:627-634.

31. Lee AM, Jepson C, Hoffmann E, Epstein L, Hawk LW, Lerman C, Tyndale RF: CYP2B6 genotype alters abstinence rates in a bupropion smoking cessation trial. Biol Psychiatry 2007, 62:635-641.

32. Brown RA, Burgess ES, Sales SD, Whiteley JA, Evans DM, Miller IW: Reliability and validity of a smoking timeline follow-back interview. Psychol Addict Behav 1998, 12:101-112.

33. Heatherton TF, Kozlowski LT, Frecker RC, Fagerstrom KO: The Fagerstrom Test for Nicotine Dependence: a revision of the Fagerstrom Tolerance Questionnaire. Br J Addict 1991, 86:1119-1127.

34. Piper ME, McCarthy DE, Bolt DM, Smith SS, Lerman C, Benowitz N, Fiore MC, Baker TB: Assessing dimensions of nicotine dependence: an evaluation of the Nicotine Dependence Syndrome Scale (NDSS) and the Wisconsin Inventory of Smoking Dependence Motives (WISDM). Nicotine Tob Res 2008, 10:1009-1020.

35. Piper ME, Piasecki TM, Federman EB, Bolt DM, Smith SS, Fiore MC, Baker TB: A multiple motives approach to tobacco dependence: the Wisconsin Inventory of Smoking Dependence Motives (WISDM-68). J Consult Clin Psychol 2004, 72:139-154.

36. Smith SS, Piper ME, Fiore MC, Baker TB: Subscale consolidation and item reduction of the 68-item Wisconsin Inventory of Smoking Dependence Motives (WISDM-68). Proceedings of the Society for Research on Nicotine and Tobacco: 21-24 February 2007; Austin .

37. Hughes JR, Hatsukami D: Signs and symptoms of tobacco withdrawal. Arch Gen Psychiatry 1986, 43:289-294.

38. Cox LS, Tiffany ST, Christen AG: Evaluation of the brief questionnaire of smoking urges (QSU-brief) in laboratory and clinical settings. Nicotine Tob Res 2001, 3:7-16.

39. Radloff LS: The CES-D Scale. Appl Psychol Meas 1977, 1:385-401.

40. Cole JC, Rabin AS, Smith TL, Kaufman AS: Development and validation of a Rasch-derived CES-D short form. Psychol Assess 2004, 16:360-372.

41. Kroenke K, Spitzer RL, Williams JB: The Patient Health Questionnaire-2: validity of a two-item depression screener. Med Care 2003, 41:1284-1292.

42. Cohen S, Lichtenstein E: Perceived stress, quitting smoking, and smoking relapse. Health Psychol 1990, 9:466-478.
43. Cohen S, Lichenstein E, Mermelstein RJ, Mclntyre-Kingsolver KO, Baer JS, Kamarck TW: Social support interventions for smoking cessation. In Marshalling Social Support: Formats, Processes and Effects. Edited by: Gottlieb BH. New York: Sage; 1998:211-240.

44. Becoña E, Vázquez FL, Fuentes MJ, del Carmen Lorenzo M: Anxiety, affect, depression and cigarette consumption. Pers Individ Dif 1998, 26:113-119.

45. Krieger N, Sidney S: Racial discrimination and blood pressure: the CARDIA Study of young black and white adults. Am J Public Health 1996, 86:1370-1378.

46. Krieger N, Smith K, Naishadham D, Hartman C, Barbeau EM: Experiences of discrimination: validity and reliability of a self-report measure for population health research on racism and health. Soc Sci Med 2005, 61:1576-1596.

47. Carver CS, White TL: Behavioral inhibition, behavioral activation, and affective responses to impending reward and punishment: The BIS/BAS Scales. J Pers Soc Psychol 1994, 67:319-333.

48. Meyers AW, Klesges RC, Winders SE, Ward KD, Peterson BA, Eck LH: Are weight concerns predictive of smoking cessation? A prospective analysis. J Consult Clin Psychol 1997, 65:448-452.

49. Borrelli B, Mermelstein R: The role of weight concern and self-efficacy in smoking cessation and weight gain among smokers in a clinic-based cessation program. Addict Behav 1998, 23:609-622.

50. Messina ES, Tyndale RF, Sellers EM: A major role for CYP2A6 in nicotine Coxidation by human liver microsomes. J Pharmacol Exp Ther 1997, 282:1608-1614

51. Mwenifumbo JC, Tyndale RF: Molecular genetics of nicotine metabolism. Handb Exp Pharmacol 2009, 192:235-259.

52. Hukkanen J, Jacob P, Benowitz NL: Metabolism and disposition kinetics of nicotine. Pharmacol Rev 2005, 57:79-115.

53. Leabman MK, Huang CC, Kawamoto M, Johns SJ, Stryke D, Ferrin TE, DeYoung J, Taylor T, Clark AG, Herskowitz I, Giacomini KM: Polymorphisms in a human kidney xenobiotic transporter, $\mathrm{OCT} 2$, exhibit altered function. Pharmacogenetics 2002, 12:395-405.

54. Dempsey D, Tutka P, Jacob P, Allen F, Schoedel K, Tyndale RF, Benowitz NL: Nicotine metabolite ratio as an index of cytochrome P450 $2 \mathrm{A6}$ metabolic activity. Clin Pharmacol Ther 2004, 76:64-72

55. Rao Y, Hoffmann E, Zia M, Bodin L, Zeman M, Sellers EM, Tyndale RF: Duplications and defects in the CYP2A6 gene: identification, genotyping, and in vivo effects on smoking. Mol Pharmacol 2000, 58:747-755.

56. Ando M, Hamajima N, Ariyoshi N, Kamataki T, Matsuo K, Ohno Y: Association of CYP2A6 gene deletion with cigarette smoking status in Japanese adults. Am J Epidemiol 2003, 13:176-181.

57. Loriot MA, Rebuissou S, Oscarson M, Cenée S, Miyamoto M, Ariyoshi N, Kamataki T, Hémon D, Beaune P, Stücker I: Genetic polymorphisms of cytochrome P450 2A6 in a case-control study on lung cancer in a French population. Pharmacogenet Genomics 2001, 11:39-44.

58. Carter B, Long T, Cinciripini P: A meta-analytic review of the CYP2A6 genotype and smoking behavior. Nicotine Tob Res 2004, 6:221-227.

59. Schulz TG, Ruhnau P, Hallier E: Lack of correlation between CYP2A6 genotype and smoking habits. Adv Exp Med Biol 2001, 500:213-215.

60. Wang H, Tan W, Hao B, Miao X, Zhou G, He F, Lin D: Substantial reduction in risk of lung adenocarcinoma associated with genetic polymorphism in CYP2A13, the most active cytochrome P450 for the metabolic activation of tobacco-specific carcinogen NNK. Cancer Res 2003, 63:8057-8061.

61. Stahl SM, Pradko JF, Haight BR, Modell JG, Rockett CB, Learned-Coughlin S: A review of the neuropharmacology of bupropion, a dual norepinephrine and dopamine reuptake inhibitor. Prim Care Companion J Clin Psychiatry 2004, 6:159-166.

62. Jefferson JW, Pradko JF, Muir KT: Bupropion for major depressive disorder: pharmacokinetic and formulation considerations. Clin Ther 2005, 27:1685-1695.

63. Faucette SR, Hawke RL, Lecluyse EL, Shord SS, Yan B, Laethem RM, Lindley CM: Validation of bupropion hydroxylation as a selective marker of human cytochrome P450 2B6 catalytic activity. Drug Metab Dispos 2000, 28:1222-1230.

64. Miksys S, Lerman C, Shields PG, Mash DC, Tyndale RF: Smoking, alcoholism and genetic polymorphisms alter CYP2B6 levels in human brain. Neuropharmacology 2003, 45:122-132.

65. Hesse LM, He P, Krishnaswamy S, Hao Q, Hogan K, von Moltke LL, Greenblatt DJ, Court MH: Pharmacogenetic determinants of 
interindividual variability in bupropion hydroxylation by cytochrome P450 2B6 in human liver microsomes. Pharmacogenetics 2004, 14:225-238.

66. Bumpus NN, Sridar C, Kent UM, Hollenberg PF: The naturally occurring cytochrome P450 (P450) 2B6 K262R mutant of P450 2B6 exhibits alterations in substrate metabolism and inactivation. Drug Metab Dispos 2005, 33:795-802.

67. Kirchheiner J, Klein C, Meineke I, Sasse J, Zanger UM, Murdter TE, Roots I, Brockmoller J: Bupropion and 4-OH-bupropion pharmacokinetics in relation to genetic polymorphisms in CYP2B6. Pharmacogenetics 2003, 13:619-626.

68. Zukunft J, Lang T, Richter T, Hirsch-Ernst KI, Nussler AK, Klein K, Schwab M, Eichelbaum M, Zanger UM: A natural CYP2B6 TATA box polymorphism $(-82 T \nabla C)$ leading to enhanced transcription and relocation of the transcriptional start site. Mol Pharmacol 2005, 67:1772-1782.

69. Stewart JJ, Berkel HJ, Parish RC, Simar MR, Syed AJAB, Wilson JT, Manno JE: Single-dose pharmacokinetics of bupropion in adolescents: effects of smoking status and gender. J Clin Pharmacol 2001, 41:770-778.

70. Benowitz NL, Jacob P, Fong I, Gupta S: Nicotine metabolic profile in man: comparison of cigarette smoking and transdermal nicotine. J Pharmacol Exp Ther 1994, 268:296-303.

71. Benowitz NL, Zevin S, Jacob P: Sources of variability in nicotine and cotinine levels with use of nicotine nasal spray, transdermal nicotine, and cigarette smoking. Br J Clin Pharmacol 1997, 43:259-267.

72. Hughes JR, Keely JP, Niaura RS, Ossip-Klein DJ, Richmond RL, Swan GE: Measures of abstinence in clinical trials: issues and recommendations. Nicotine Tob Res 2003, 5:13-25.

73. Benowitz NL, Jacob P, Ahijevych K, Jarvis MJ, Hall S, LeHouezec J, Hansson A, Lichtenstein E, Henningfield J, Tsoh J, Hurt RD, Velicer W: Biochemical verification of tobacco use and cessation. Nicotine Tob Res 2002, 4:149-159.

74. Murray RP, Connett JE, Lauger GG, Voelker HT: Error in smoking measures: effects of intervention on relations of cotinine and carbon monoxide to self-reported smoking. The Lung Health Study Research Group. Am J Public Health 1993, 83:1251-1257.

75. Cummings SR, Richard RJ: Optimum cutoff points for biochemical validation of smoking status. Am J Public Health 1988, 78:574-575.

76. Jacob P, Wilson M, Benowitz NL: Improved gas chromatographic method for the determination of nicotine and cotinine in biologic fluids. J Chromatogr 1981, 222:61-70.

77. Shiffman S: Nicotine lozenge efficacy in light smokers. Drug Alcohol Depend 2005, 77:311-314

78. Gariti P, Lynch K, Alterman A, Kampman K, Xie H, Varillo K: Comparing smoking treatment programs for lighter smokers with and without a history of heavier smoking. I Subst Abuse Treat 2009, 37:247-255.

79. Cox LS, Bronars CA, Thomas JL, Okuyemi KS, King G, Mayo MS, Ahluwalia JS: Achieving high rates of consent for genetic testing among African American smokers. Nicotine Tob Res 2007, 9:711-716.

80. Jorenby DE, Leischow SJ, Nides MA, Rennard SI, Johnston JA, Hughes AR, Smith SS, Muramoto ML, Daughton DM, Doan K, Fiore MC, Baker TB: A controlled trial of sustained-release bupropion, a nicotine patch, or both for smoking cessation. N Engl J Med 1999, 340:685-691.

81. Lerman C, Roth D, Kaufmann V, Audrain J, Hawk L, Liu A, Niaura R, Epstein $L$ : Mediating mechanisms for the impact of bupropion in smoking cessation treatment. Drug Alcohol Depend 2002, 67:219-223.

82. Cox LS, Patten CA, Niaura RS, Decker PA, Rigotti N, Sachs DP, Buist AS, Hurt RD: Efficacy of bupropion for relapse prevention in smokers with and without a past history of major depression. J Gen Intern Med 2004, 19:828-834.

83. Harris KJ, Okuyemi KS, Catley D, Mayo MS, Ge B, Ahluwalia JS: Predictors of smoking cessation among African-Americans enrolled in a randomized controlled trial of bupropion. Prev Med 2004, 38:498-502.

84. Augustson EM, Wanke KL, Rogers S, Bergen AW, Chatterjee N, Synder K, Albanes D, Taylor PR, Caporaso NE: Predictors of sustained smoking cessation: a prospective analysis of chronic smokers from the alphatocopherol Beta-carotene cancer prevention study. Am J Public Health 2008, 98:549-555.

85. Ferguson JA, Patten CA, Schroeder DR, Offord KP, Eberman KM, Hurt RD: Predictors of 6-month tobacco abstinence among 1224 cigarette smokers treated for nicotine dependence. Addict Behav 2003, 28:1203-1218
86. Hyland A, Garten S, Giovino GA, Cummings KM: Mentholated cigarettes and smoking cessation: findings from COMMIT. Tob Control 2002, 11:135-139.

87. Nollen NL, Mayo MS, Sanderson Cox L, Okuyemi KS, Choi WS, Kaur H, Ahluwalia JS: Predictors of quitting among African American light smokers enrolled in a randomized, placebo-controlled trial. J Gen Intern Med 2006, 21:590-595.

doi:10.1186/1745-6215-12-22

Cite this article as: Cox et al.: Design, baseline characteristics, and retention of African American light smokers into a randomized trial involving biological data. Trials 2011 12:22.

\section{Submit your next manuscript to BioMed Central and take full advantage of:}

- Convenient online submission

- Thorough peer review

- No space constraints or color figure charges

- Immediate publication on acceptance

- Inclusion in PubMed, CAS, Scopus and Google Scholar

- Research which is freely available for redistribution

Submit your manuscript at www.biomedcentral.com/submit
C Biomed Central 